\title{
Misogyny, Racism, and Islamophobia: Street Harassment at the Intersections
}

\section{Hannah Mason-Bish \& Irene Zempi}

\section{Abstract}

Veiled Muslim women are at an increased risk of street harassment in the current political and economic climate. Their visibility, combined with their popular portrayal as culturally dangerous or threatening means that they are vulnerable to receiving verbal and physical threats, which can be misogynistic and Islamophobic in nature. Drawing on 60 individual and 20 focus group interviews with Muslim women in the United Kingdom who wear the niqab (face veil) and had experienced harassment in public, this qualitative study details their lived experiences. It argues that an intersectional analysis is crucial to understanding the nuances of their lived experiences and the impact street harassment has on their lives. The findings demonstrate that street harassment can produce a hostile environment for veiled Muslim women, which can have a terrorizing effect, limiting their full participation in the public sphere.

\section{Introduction}

Within the current post-Brexit climate, veiled Muslim women are facing increased risks of attacks in the United Kingdom. The anti-Muslim hate monitoring group Tell MAMA reported in their annual survey for 2016 that there was a significant rise in hate crimes against Muslims being reported to them after the vote to leave the European Union. Research found that not only are Muslim women more likely to be attacked than Muslim men but also their experiences demonstrate misogynistic and Islamophobic undertones (Zempi \& Chakraborti, 2014). The number of people 
identifying as Muslim has increased by 1.2 million between the 2001 and 2011 census sweeps (Casey, 2016). Our research took place at a time when Muslims are having their faith and beliefs questioned more vocally by some sections of society. A 2016 ComRes poll noted that $43 \%$ of 2,000 adults surveyed felt that Islam was a negative force in the United Kingdom. A recent government report suggested that this was partly caused by concerns over integration, immigration, and perceptions of backward religious practices (Casey, 2016).

Certainly, not all Muslim women wear the headscarf and/or face veil, and some are not covered at all. However, as Perry (2014) points out, Muslim women and girls are extremely vulnerable to street violence motivated by their visible status as Muslims. This also has to do with the controlling images of veiled Muslim women that render them especially attractive and available targets. Bullock and Jafri (2002) highlight three "personas" that Muslim women are perceived to occupy in the popular imagination, and, thus, define what Muslim women "are supposed to be and do":

The first is the "harem belly-dancer character," the mysterious and sexualized woman of the "Orient"; the second is "the oppressed Muslim woman," often represented as the hijab (headscarf) wearer or the woman who is unable to drive; and, finally, there is the "militant Muslim woman," often shown in hijab with a gun and military clothes. (p. 36)

Along similar lines, Zempi \& Chakraborti (2014) point out that veiled Muslim women are routinely portrayed as oppressed, "culturally dangerous," and "threatening" to the Western way of life and to notions of public safety and security by virtue of being fully covered in the public sphere. Correspondingly, the visibility of veiled Muslim women must also be understood in the current climate of international legal reforms, which 
have attempted to criminalize wearing the niqab in public places. France was the first to ban face covering, when, in 2009 , then president Nicolas Sarkozy said that such clothing was "not welcome" and that legislation would protect women who were being forced to wear it. There have been calls by some members of parliament (MPs) to ban the niqab in Britain, following recent bans in other European countries such as Belgium, Switzerland, the Netherlands, Italy, and Bulgaria. Such legislation alludes to a need to protect Muslim women from an oppressive male family member, which infantilizes them and makes them appear weak. Furthermore, it promotes a message of intolerance and indicates that Muslim women who wear the niqab do not belong in secular Western countries. Both messages have a similar impact which is to encourage Muslim women to stay home and out of public view.

Although there is increasing literature on street violence against women generally, there is relatively little scholarly work examining the experiences of Muslim women who wear the niqab. Allen's (2015) study provided a significant contribution to this gap by interviewing veiled Muslim women about their experiences and concluding that incidents were often at the intersection of religion and gender. However, there still exists a lack of engagement with wider literature on street harassment, which draws out more general gendered experiences. Drawing on 60 individual and 20 focus group interviews with Muslim women who wear the niqab, this article reflects upon their lived experiences in public spaces. We argue that it is essential to take an intersectional approach by looking at how they are victimized along Islamophobic and misogynistic lines. Our aim with this article is to demonstrate the religious and gender dimensions of veiled Muslim women's experiences in public. This does not just mean acknowledging that Muslim women have different experiences, but 
thinking more critically about how key aspects of their identity intersect to define their place in the social world.

\section{Understanding street harassment and intersectionality}

In this article, we employ the term "street harassment" because it is inclusive in terms of capturing different forms of harassment of women in public (rather than merely sexual harassment). As Davis (1994) points out, there are three certain key characteristics associated with street harassment: the locale, the gender of and the relationship between the harasser and the target, and the reference to body parts. Typically, the targets of street harassment are female, whereas the harassers are male; the harassers are unacquainted with their targets, and the forum is a public one (although the content of the speech, if any, is not intended as public discourse; Bowman, 1993). From this perspective, street harassment is defined as "the unsolicited verbal and/or nonverbal act of a male stranger towards a female, solely on the basis of her sex, in a public place" (Laniya, 2005, p. 100). Both men and women can experience street harassment; however, most victims are women.

Vera-Gray (2016) argues that empirical studies of street harassment, its prevalence, manifestations, effects, and the meanings it holds for both, the men who practice it and the women who experience it, are limited. Reasons for the "invisibility" of women's experiences of street harassment include trivialization (Tuerkheimer, 1997), normalization (Bowman, 1993; Larkin, 1997), and the ways in which practices in public or semipublic places do not receive the same scrutiny as practices in private places (Gardner, 1995; Goffman, 1990). With the exception of Kelly (1988), Randall (1987), and Wise and Stanley (1987), public space as an arena, and everyday life as the context, are largely absent from mainstream work on sexual harassment. 
Furthermore, scholarship on street harassment has tended to overlook the issue of intersectionality in relation to victim experiences. Coined by Crenshaw (1989), the concept of intersectionality was introduced to explain the way that multiple systems of oppression construct our identities and also our access to power and privilege. In relation to violence and hostility, difference is obscured both in an attempt to understand the victim experience and in relation to how campaigners and policy makers might exclude issues of gender, religion, or other identity characteristics. This is particularly the case for the lived experiences of "other" women such as Muslim women who wear the niqab in public in the United Kingdom.

Against the backdrop of the "War on Terror" and the popular perceptions of gender oppression in Islam, the visibility of the niqab renders Muslim women the "ideal" target for street harassment (Zempi \& Chakraborti, 2014). In this regard, wearing the niqab marks Muslim women more readily visible as "soft," "easy," and "convenient" targets to attack. Veiled Muslim women often occupy intersecting positions in terms of religion, gender, and appearance coupled with other aspects of their identities, and this defines their experiences of street harassment. Abu-Ras and Suarez (2009) highlight the complexity of Muslim women's identities: (a) their gender status as women, who generally face more discrimination in access to educational, financial, health, and social resources; (b) their cultural identity that is shaped by structural social and cultural constraints provided by gender socialization and patriarchal processes; (c) their status as immigrants and minorities in a Western country, and the resulting social and economic marginalization; and finally (d) their Muslim dress code that symbolizes modesty and physical integrity, and identifies them from nonMuslims, marking them as targets for hate crimes, discrimination, and possible violations of their bodily integrity. 
At the same time though, this does not mean that street harassment has one meaning for veiled Muslim women and a different meaning for all other women; rather, veiled Muslim women can experience street harassment in ways that are both similar to and different from that experienced by all other women. According to Davis (1994), truly to understand any woman's experience, it is crucial to think of her as embodied and not as an individual experiencing street harassment on various, nonintersecting axes. It is argued that "we cannot hope to understand the meanings of a person's experience, including her experiences of oppression, without first thinking of her as embodied, and second thinking about the particular meanings assigned to that embodiment" (Davis, 1994, p. 214). To illustrate this, Lloyd (2005) points out that Black women do not experience racism because they are Black, and sexism because they are women; they experience both simultaneously on the basis that "racism and sexism interlock, they modulate and inflect one another" (p. 45). Taking a similar position, Spelman (1990) states that "sexism and racism do not have different objects" (p. 12). Such insights can be revealing, for example, the work of Fogg-Davis that examined the victimization of Black lesbians. He noted that it was important to question the "interplay between civic behaviours and intersection structural inequalities" and that their victimization drew upon heterosexism, colonialism, and slavery (Fogg-Davis, 2006, p. 57). Such a detailed examination has not been carried out in relation to the experiences of veiled Muslim women.

For Muslim women, their experiences can sit at the intersection of religion and gender coupled with other aspects of their identity. In essence, these aspects of identity define not only their everyday life experiences but also specifically their experiences and responses to street harassment. For many, the niqab itself is a 
symbol of gender oppression and "extreme" Muslim values, meaning that perpetrators feel emboldened to enact both their Islamophobic and misogynistic feelings on Muslim women (Zempi \& Chakraborti, 2014). Literature on street harassment demonstrates that it is commonplace for women to take safety precautions in public such as altering their appearance or clothing (Bowman, 1993). For Muslim women, this gendered approach takes on an added dimension because it might mean removing their niqab, which has implications for their religious sense of self and practicing their religion.

\section{Methods}

\section{Overview of research design}

The research took the form of a qualitative study based on semi-structured interviews carried out between 2011 and 2012 with Muslim women who wear the niqab. The research took place in Leicester. Specifically, the study comprised 60 individual and 20 focus group interviews with veiled Muslim women who had experienced anti-Muslim hostility in public places. The topics covered in the interviews and focus groups included (a) nature and frequency of harassment; (b) impact of harassment on victims, their families, and wider communities; (c) women's coping mechanisms; and (d) effectiveness of criminal justice responses to this problem. The interviews, undertaken by the second author, typically ranged from 1 to 2 hours, with an average interview length of 1 hour. Participation in the study was voluntary. All the women who took part in the study wore the niqab at the time of fieldwork. There was no overlap between the women who participated in the interviews and in the focus groups. Of the 60 veiled Muslim women who took part in

individual interviews, 1 83\% $(n=50)$ were born into Islam and $17 \%(10)$ had converted to Islam. The largest ethnic group of participants classified themselves as 
Asian (Indian, Pakistani, Bangladeshi, and Asian other-70\%, 42), followed by Black (either Black Caribbean, Black African, and Black Other-13\%, eight), and White (British, Irish, and Other-17\%, 10). The majority of participants had lived in Leicester for 5 years or more $(67 \%, 40)$.

\section{Sampling}

Women were invited to participate in the study based on the premise they had experienced harassment in public. Using convenience sampling, prospective participants were identified through local Muslim organizations including mosques, Muslim schools, and Islamic centers, as well as local Muslim university student societies, and Muslim women's groups. The study was advertised through these organizations, and women could contact the researcher (that is, the second author) directly to arrange for an interview (the researcher's contact details were included in the call for participants) on the basis that they had experienced harassment in public. Prior to conducting the interviews, the researcher explained to prospective participants the scope of the study, that is, examining their experiences of harassment in public. Participants who had not experienced harassment in public would be excluded from the study; however, this was not the case as all the participants did report some form of harassment, whether anti-Muslim, racist, and/or misogynistic.

An advantage of employing these organizations for participant recruitment was that individuals were introduced to the study by a familiar, trusted organization. This alleviated any concerns that participants might have had about taking part in the study, thus potentially increasing participation in the study. Participants unaffiliated to any local Muslim organizations or groups were also recruited through snowball 
sampling. As with convenience sampling, snowball sampling is a type of nonprobability method, which is particularly appropriate when the population of interest is "hidden" or "hard to reach" and there is a lack of sampling frame of the target group (Patton, 1987).

Individual interviews took place at women's homes or at the university where the researcher was working at the time of the fieldwork. Conducting interviews at the university was offered as an alternative to participants who did not wish for the interview to take place at their home. The university was a safe, private location to conduct the interviews, for both the researcher and the participants (when arranging an interview at the university, a room was booked to ensure privacy and to minimize interruptions). Conducting interviews at women's homes was useful for some participants as it minimized the inconvenience of leaving the house as some women had caring responsibilities of young children and/or elderly family members. However, some women chose the university as their preferred location for the interviews as they might not have been able to fully disclose their experiences of victimization if other family members were present in their home during the interview.

Focus group interviews were conducted at local Muslim organizations such as mosques, Islamic centers, and Islamic educational institutions. The focus group participants were already at these premises for religious purposes such as praying and learning or teaching the Quran. Most groups were already established in certain classes, and participants either would take some time off their classes to participate in a focus group interview or would join in the next session as soon as they finished their activities. It is likely that participants felt comfortable and secure because they were interviewed in environments that they were mostly familiar with. This approach reinforced notions of good interview rapport and trusting relationships between the 
researcher and the researched (Curtis \& Curtis, 2011). It also encouraged openness and honesty from the women, particularly because of the sensitive nature of the discussion.

\section{Data analysis, authenticity and reflexivity}

With the exception of one individual, the rest of participants consented to their interviews being audio recorded, and the material was subsequently transcribed and analyzed using grounded theory (Glaser \& Strauss, 1967). Grounded theory, which is based on an inductive approach, involves developing a "story" that emerges from the data. Within this framework, participants' responses are construed as evidence of what they think and feel and how they interpret the social world (Glaser, 1992). In this case, verbatim transcripts are essential for grounded theory analysis as they capture information in participants' own words, phrases, and expressions as well as providing "rich" detail. Within a grounded theory framework, the data were reviewed and coded to produce categories consistent with issues of thematic interest. Nvivo 9 was used to code the data under broad themes of women's victimization, and then patterns and subthemes were identified within broad themes such as the nature, frequency, and impact of victimization; women's coping mechanisms; and prevention of victimization.

As Payne (2004) points out, the terms and concepts used to demonstrate rigor in quantitative research-including reliability, validity, representativeness, generalizability, and objectivity-are problematic for qualitative research. Because most qualitative research methods of analysis are concerned with the interpretation of data and the researcher's role in this is explicitly acknowledged, the dichotomy between subjectivity and objectivity is not supportable. Rather, qualitative 
researchers must demonstrate the methodological rigor of their work, and be clear and explicit in the claims made when research is written up or presented. This indicates that researchers need to use reflexivity throughout the research process to recognize the potential influence of the researcher(s) on the research design, participant selection, as well as data collection and interpretation (Hennink, Hutter, \& Bailey, 2011).

Indeed, as an orthodox Christian female individual,3 the researcher was sometimes perceived as an "outsider" by her participants due to her religion. To gain an insider's perspective, the researcher used different techniques such as using a semistructured interview guide to prompt the data collection; employing careful listening skills; establishing rapport and trust with participants; creating a safe, comfortable environment for participants; asking questions in an open, unthreatening way and in a friendly colloquial manner; showing empathy toward participants; and motivating them to tell their stories in detail by using probes. For example, asking questions in a nonthreatening, friendly way included framing questions in a manner that was nonleading, using neutral language (rather than using emotive language) and using open-ended questions. In addition, throughout the research cycle, the researcher asked for feedback from the participants, and received critical remarks on the research design, which were implemented, thus enhancing the quality of the study. For example, the researcher found that interview questions posed in a more academic language were not immediately understandable by some participants and, thus, she decided to pose questions in colloquial language. Amending the language of the questions posed was important to get an insight into participants' perceptions, emotions, feelings, and beliefs, and, thus, truly understand their experiences.

Other aspects of the researcher's identity also contributed to her "outsider" status 
such as her Western style of dress. In this case, the leaders of the mosques, Muslim schools, and Islamic community centers (that the researcher visited to conduct the focus group interviews) advised her to dress and behave in a religiously and culturally appropriate manner when visiting these places. For example, the researcher was asked to dress modestly, including wearing a long loose dress (preferably black) and covering her hair with a hijab (headscarf) when conducting focus group sessions at mosques. The fact that the researcher conformed to this advice eased access to participants, and helped to develop trust and rapport with them. As Zubair, Martin, and Victor (2012) point out, researchers' bodily appearances and bodily actions, adaptations, and interactions are important markers of their identity in the fieldwork. Okely (2007) suggests that researchers often have to learn to adapt their bodily performances and actions-including the way they dressto fit in with, and be accepted among, those they are researching, especially when they are closely scrutinized and instructed. This demonstrates the important role the researcher's body and behavior may play in developing (or hindering the development of) trust and rapport with participants. This discussion shows that research design needs to take into account the religious and cultural context of the community. Awareness of cultural and religious norms is vital for negotiating insider/outsider dynamics through showing respect for participants' culture and religion.

\section{Street harassment}

\section{$\underline{\text { Nature and extent }}$}


All the participants reported feeling unsafe in public spaces because of concerns that they were likely to be approached, intimidated, threatened, or attacked. Such concerns were based on previous experiences ranging from verbal and nonverbal street remarks to serious incidents of stalking and physical assaults. In particular, participants experienced verbal and nonverbal sexual harassment in public spaces. Participants reported that unknown men on the street made sexual comments and/or sexual noises at them (often accompanied by sexual gestures). In some cases, individuals asked them questions about their sexual life and/or their sexuality. Also, participants were subjected to wolf whistling, catcalling, and sexist jokes.

The visibility of the niqab confounds public norms, partly because of the niqab's message of sexual unavailability (Zempi \& Chakraborti, 2014). This symbolism brings the veiled Muslim woman very visibly into the public sphere where she simply cannot walk by unnoticed. In this context, the niqab symbolizes the sexual "nonavailability" of Muslim women. As a result, men may find it difficult to forgive those who "disrupt" the "pattern of the masculine gaze" (Franks, 2000). Correspondingly, unknown men on the street often "demanded" that participants unveiled themselves by taking the niqab off, as indicated in the comments below.

I want to cut that black thing off your face! (Halimah)

Show me what you're wearing under there! (Ruqiia)

Give us a flash! (Alima)

In the eyes of their harassers, veiled Muslim women participated in the public sphere to entertain and please men (Kissling \& Kramarae, 1991). This led to participants feeling objectified and reduced to their body parts. As Kissling (1991) points out, 
street harassment remarks often refer to parts of the body not available for public examination. Accordingly, participants were sometimes "challenged" by unknown men walking by on the street, who often assumed that women wore the niqab because they were "ugly," as the following quotes demonstrate.

What's that on your face? Why are you covering it? (Sarah)

Why do you have a mask on? Are you really ugly under there? (Focus group participant)

If participants were traveling with their children, it was also common for unknown individuals to make comments such as, "Why are you covered up and your children are not covered up?"

\section{Performance of Gender}

Participants felt that performing gender inappropriately was key to triggering such comments, as indicated in the following focus group discussion.

\section{Participant A:}

We are very different to the average non-Muslim woman. We are doing everything that the media tells us we shouldn't be doing in terms of how women should dress and behave.

Participant B:

In Western societies men are used to seeing women in all their glory really, aren't they? I think men appreciate the fact that they can see a woman's face and that they can see her figure. They probably feel deprived of this opportunity because they 
can't assess a Muslim woman in the same way that they can assess a Christian, Sikh or Hindu woman.

Participant C:

They just don't want this image [of the veiled Muslim woman] to be out there because that image is not "pleasant" to the Western world, that image is not a symbol of the sexual exploitation of women.

Participants also argued that performing gender "inappropriately" coupled with practicing Islam as pious Muslim women was seen as a symbol of segregation and unwillingness to "integrate" into British society. To this end, street harassers "punished" veiled Muslim women for their deviant behavior and assumed that veiling represented a rejection of Western values. It would be interesting to explore in a further study the extent to which other Muslim women experience this perception. Relatedly, this issue was debated in a focus group interview at an Islamic center.

Participant A:

If they get rid of Muslims then they will have a white Christian England.

Participant B:

I don't think it is about being Christian. I think it's about being like them. Hindu and Sikhs are brown. They are Asians but they drink, they go clubbing, women wear short skirts. They'll do everything like them. It's about socialising so they feel more integrated with them. They feel they are the same.

Participant C: 
You're right, especially the drinking thing kind of unites them. They think "We might be different colours but we are the same, we drink, we club, we dress the same, we are mixing" but we as Muslims don't do what they do. We dress differently. We say no to drinking. We won't go clubbing. Yeah there are Muslims that do go but generally you won't see that many Muslims going to clubs. Even if they go, you can't tell that they are Muslim. Even we as Muslims can't recognise them. If someone is not dressed as a Muslim you can't tell if they are Muslim or not.

In their research with veiled Muslim women, both Bullock (2002) and Abu-Lughod (2013) highlight Muslim women's perceptions of the hijab and/or niqab as a form of emancipation and agency. Bullock (2002) states that Muslim women "whose grandmothers and mothers may have fought to uncover, started wearing the hijab and niqab" (p. 85). However, although freedom of choice and individual agency are among the most cherished values in contemporary Western societies, the woman who freely chooses to wear the niqab often provokes public hostility (Zempi \& Chakraborti, 2014). The "refusal" of veiled Muslim women to conform to the expectation of being "the object of the gaze" constitutes a disruption of power relations in the public sphere. In this context, veiled Muslim women's bodies become a medium on which to inscribe hostility and enmity (Perry, 2014). And, the body is, in the words of Eisenstein (2006), "a horribly powerful resource for those who wish to conquer, violate, humiliate, and shame" (p. 186). Like many women of color, Muslim women are sexualized, such that they are reduced to their bodies (Perry, 2014). This reflects a familiar dichotomy that characterizes their perceived identities. For White women, there is the Madonna/whore duality; for Black women, there is the Jezebel and Mammy distinction; whereas, for Muslim women, there is distinction between the 
sexual belly dancer and the oppressed woman who is in need of saving (Perry, 2014).

Furthermore, participants reported being subjected to name-calling, which would be difficult to define as sexual harassment per se; yet, this type of harassment is part of some Muslim women's lived experiences of wearing the niqab in public places in the United Kingdom. To illustrate this, participants reported being used as a form of "entertainment." For example, they were called names such as "Ninja," "Catwoman," "Batman," "Darth Vader," "Ghost woman," "Bin bag," "Letterbox," "Postbox," "Witch," and "Walking Coffin." Moreover, participants noted that they had been subjected to swearing such as "Fucking freak," "Muslim bitch," and "Muslim whore." In addition, a couple of participants reported that people on the street sometimes took photographs of them (without asking their permission), whereas others revealed that they had been followed and/or stalked, illustrations of which are presented below.

I was walking on the street [in London] and this guy was following me. He was saying "Come on show me your face, show me your face" and after a few streets I took my niqab off and showed him my face. I was so scared that I took it off. After a couple of streets down I put it back on again. (Salimah)

I was walking in town [Leicester city centre] and this man followed me home. He saw I was a single woman in the house with a child. I didn't have money to buy the curtains. He used to come and knock on the door. I told the Council what was going on and they gave me a house in another estate. (Johara)

The Niqab as a Terrorist "Threat" 
Veiled Muslim women not only are characterized as exotic and/or as oppressed but also are represented as mysterious, dangerous, and threatening (Perry, 2014). To this end, veiled Muslim women are perceived as "agents" of terrorism or as tools of Islamist terrorism aiming to infiltrate the West (Freedman, 2007). Participants were often perceived as a security or terrorist "threat." In some cases, they were being called names such as "mothers of suicide bombers." Also, the following comments demonstrate that veiling was perceived as a camouflage for a terrorist.

Are you carrying belts full of explosives? (Jahidah)

When are you going to blow us up? (Shelina)

Why are you dressed like that? Are you a suicide bomber? (Amtullah)

\section{Physical Harm}

A minority of participants were victims of serious physical harm. They reported being pushed, slapped, spat at, shoved or had their niqabs pulled off by unknown men on the street. In some cases, they had things thrown at them (such as alcohol, water bombs, bottles, eggs, take-away food, rubbish, and stones) or they had a weapon (such as a knife) being used against them. Such incidents were demonstrated in Armstrong's (2016) study of sex workers, which found that while they experienced the common forms of "low level" street harassment, they were more vulnerable to escalating abuse, which had more "sinister undertones" (p. 292). Armstrong's research has connections with the current study because it also features women facing specific forms of street harassment because of what they represent. They share experiences of hostility and dehumanization as well as being at risk when in certain public spaces. Participants in the present study also reported incidents where 
passing vehicles attempted to run them over. These findings show very strong similarities with qualitative research into the experiences of Muslim women who wear the niqab in other European countries, namely, Belgium, Denmark, France, and the Netherlands (Brems, 2014). For example, veiled Muslim women in the Netherlands reported regularly being confronted with people who scolded, insulted, or spat at them (Moors, 2009, 2014). Echoing these experiences, veiled Muslim women in France described a stream of violent insults in public places including being violently pushed, spat on, and having their niqab pulled off (Bouteldja, 2011).

Participants noted that the typical perpetrator was male (and unknown to them). Specifically, participants' accounts suggested that perpetrators were usually White men, aged between 16 and 25 years. However, participants argued that they were sometimes targeted by members of ethnic and racial minorities (including EU nationals) as well as from fellow Muslims. In the latter case, the abuse came from members of the Muslim community, who were "Westernized" or "nonpracticing" Muslims. However, it is important to note that Muslim women who do not veil are also subject to discrimination on the streets (Zempi \& Chakraborti, 2014). In very few cases, where street harassers were female, this involved cases of verbal abuse and name-calling rather than physical violence or stalking. For Davis (1994), although women can and do in fact make comments to other women, a qualitative difference exists; women's comments directed toward other women are not situated in the same place of power as are men's comments. However, they do demonstrate an interesting perception of veiled Muslim women as performing gender differently and, perhaps, in a way that some female perpetrators do not like. The same situation was found in Armstrong's (2016) study where sex workers reported some attacks from women, which might be evidence of an internalized misogyny and also a public 
scolding of them "for stepping outside of the boundaries of acceptable female behavior" (p. 291).

Finally, it is important to point out that such experiences were not one-off, discrete, or isolated incidents; rather, they were part of a process of being targeted in public. Relatedly, very few participants reported these experiences to the police. Participants gave a range of reasons for not reporting but the most popular reason was that they did not think it was serious enough to report. This was followed by concerns about being blamed and feeling ashamed/embarrassed about what had happened to them. Finally, some participants did not think that what had happened to them could be classed as a crime per se. Similarly, Larkin (1997) found that everyday incidents of street harassment were so normalized that they were rarely seen as "harassment." Vera-Gray (2016) highlights the limitations of criminalizing behaviors that are extensions of commonly accepted gender relations.

\section{Street harassment: Impacts}

\section{Geography and boundaries of safety}

The most significant impact on the lives of veiled Muslim women in the research was the increased level of fear or vulnerability that they felt. Sometimes, this fear would happen before even leaving the home and in the anticipation of going outside. Such experiences concur with other academic studies on street harassment, for example, the work of Ilahi who noted that the women described having to "psychologically prepare yourself to go out and run a simple errand" (llahi, 2009, p. 62). This level of preparation was commonly noted among participants in this study, who would evaluate the likelihood of attack based on a number of factors. Many identified that being in a non-Muslim area might make them more likely to be targeted because of 
their visibility as practicing Muslim women. Some felt safer nearer home, although this depended upon previous experience of localized harassment. For example, one focus group participant noted that she had experienced criminal damage of her home and also threats of eggs being thrown at her when she left the house. So, for her, the immediate area surrounding her home was where she felt less safe.

This awareness of geography and boundaries of safety has much in common with wider experiences of street harassment. Ilahi describes this as a "discursive negotiation" of urban space and this has the effect of excluding women from certain public spaces or at least impinging upon their free movement (llahi, 2009, p. 56). According to Davis (1994), street harassment genderizes the street by institutionalizing male privilege in, and "ownership" of, the public street, thereby excluding women. From this perspective, street harassment allows men to establish the boundaries that define women's participation in the street. As such, street harassment excludes women by demarcating the street as "male space," which maintains and perpetuates the public/private distinction in a gendered form (Davis, 1994). Bowman (1993) notes that street harassers create a hostile environment on the street, implicitly informing their targets that they are not "welcome." From this perspective, to be a woman in public is to be available for men's comments.

Street harassment genderizes the street by distributing power in such a way that perpetuates and reinforces the gender hierarchy (MacKinnon, 1987). In light of this, the psychological pressures of running even a simple errand were significant (Ilahi, 2009). The participants in this study took safety seriously, but not only because of the fear of attack. A number of women felt that it was a central part of their religion. In one focus group, it was noted that "In Islam you have to look after yourself" and that "In our religion, we are supposed to keep ourselves safe." This imperative 
placed added pressure on the women as they weighed up how they might negotiate safe areas while honoring the tenets of their faith.

\section{$\underline{\text { Sexual Terrorism }}$}

The findings show that street harassment produced an environment of sexual terrorism. This refers not only to the visibility of the Muslim woman wearing a niqab but also about perceived issues of vulnerability that women generally might possess. These perceptions were often connected to their feeling that attacking or removing the niqab was a form of sexual assault. As Maha notes,

Taking the veil off is equal to rape really. I was walking down the street in the local area [Highfields, Leicester] and there were three white men in their early 20s. They took my niqab off from behind. I tried to conceal my face with my scarf and then when I tried to retrieve my niqab they wanted to take a look at me. They bent down to see what I looked like and then they chucked it on the floor.

It is important to recognize that street harassment mirrors a larger system of sexual terrorism. Kissling (1991) defines sexual terrorism as a "system by which males frighten and, through fear, control and dominate females" (p. 456). As Davis (1994) points out, recognizing street harassment's role in sexual terrorism is crucial to understanding its potential to harm. From this perspective, street harassment provokes in women a fear of rape, acting as a salient warning of the omnipresent threat of physical and/or sexual violence (Kissling, 1991). Regardless of whether there is the possibility of actual rape, street harassment reminds women of their vulnerability to sexual violence in general, and intensifies the fear of the possibility of rape (Davis, 1994). As a precursor to rape and an escalator of the fear of rape, street 
harassment entraps women in a sexually terroristic environment (Davis, 1994). Iman concurred, suggesting that

Although I don't have any bruises to show from the assault, I am damaged and harmed inside as if I have been sexually assaulted.

These comments demonstrate how important an intersectional understanding of women's experiences is. In his study of Black lesbian experiences of street harassment, Fogg-Davis (2006) observes that street harassment, like rape, is about asserting male dominance over women in "situations where women appear vulnerable" (p. 65) and that it indicates an imbalance of power, which is "connected to systems of patriarchy, racism and homophobia" (Fogg-Davis, 2006, p. 74). For the women in the present study, the forced removal of the niqab was often tied to male entitlement-or the perpetrator's frustration at the inability to visualize the female body. As mentioned earlier, participants spoke of men demanding "show me your face," "give us a flash," or "show me what you're wearing under there." Bowman (1993) writes that such invasions are like a rape, where someone is forced into your private space. Comments were often accompanied by catcalls, wolf whistles, and sexual noises. These inherently sexual and misogynistic incidents when accompanied by a physical removal of clothing demonstrate the intersections of religion and gender in the experiences of veiled Muslim women. As Fogg-Davis (2006) also notes, this simultaneous embodiment can mean that women are between categories of religion and gender and the complex psychological impacts are rarely attended to in policy or practice. We would suggest that the gendered nature of much hate crime is often overlooked by policy makers and practitioners, meaning that the nuances of the victim experience and their relative impacts can be missed. 


\section{Street harassment: Strategies}

\section{Safety work}

In classic studies of street harassment, scholars have noted the myriad strategies that women employ in their attempts to avoid being victimized. Liz Kelly (1988) coined the phrase "safety work" to describe the preparations and coping strategies that all women employ when negotiating public space. Our participants invested considerable thought into their geographic movements. This was partly based on previous experience, demonstrating again how women bring their biographic experiences to their current fears of street harassment. Some participants decided to drive or take a bus or taxi (instead of walking) to avoid street harassment. In some cases, participants changed traveling routes and made decisions not to venture into the public on certain days/times. Some participants chose not to go out at all.

The women interviewed for this research expressed strongly how their sense of identity was harmed not just by the incidents but by feeling compelled to unveil themselves. This had a very real impact on many women's sense of self and identity. For example, a participant who advised her daughter not to wear the niqab on a trip to Paris said that it made her daughter "feel bad." Another noted that the niqab is supposed to be a symbol of protection, but ironically to protect herself, she sometimes removed it. Participants did feel that they had committed a "sin," which increased their feeling of self-blame and guilt. Tashia said,

Since I took it off, it feels like l've committed a really big $\sin .$. . I should have fought back, I shouldn't have removed it. 
As Laniya (2005) points out, a member of a minority group that is consistently marginalized, blamed, and victimized may be more likely to attribute the occurrence of street harassment to herself and see herself as the cause of such harm. Thus, this woman may internalize the blame that a dominant group has placed on her. When a person blames herself, she is less likely to identify an experience as injurious, and even if she does recognize the experience as injurious, she is less likely to externalize the harm and blame someone other than herself (Laniya, 2005). That stated, some participants felt judged from within their community for deciding to take it off as a safety measure. Yara expressed this sentiment:

The ladies who wore niqabs were quite horrible to me. They judged me for taking it off. They said, "Oh that's come off, so does that mean that everything else is coming off?"

Such a sense of shame or lack of community support is not uncommon from women who alter their clothing to avoid street harassment. They too might feel a sense of letting their Muslim sisters down, or of being judged by others. As Bowman (1993) writes, the intent of street harassment is to remind women of their gender identity and this is achieved by teaching women to "associate their bodies with shame, fear and humiliation" (p. 541). For Muslim women, this is tied to decisions over where and when to wear the niqab, and what response this might glean from members of the public, their own family, or community. As such, it adds layers of complexity to their harm. As Ilahi (2009) has suggested, their social positions are interwoven into their experiences of negotiating public space.

\section{Managing Presentation of Self}


Other strategies employed by participants included altering the niqab to manage the presentation of self. One focus group participant suggested that she would use a range of colors and sizes in her niqabs, so as not to appear "too black in the face." Another said that she would use color because it looked "more friendly" and less "hostile." In this regard, they were grappling with concerns not only over their desire to veil but also to avoid being attacked. For Davis (1994), street harassment forces women to alter their behavior, thus further oppressing women by denying them the opportunity to make an authentic choice of self. The denial of a woman's "authentic choice of self" by externally imposing on her the conditions in which she lives is also perpetuated by the existence of stereotypes. For some White British Muslims, they would in fact cover more of their body to avoid being perceived as a "traitor" for supposedly "betraying" British values and Christianity by converting to Islam. Some participants noted that they would wear an additional eye veil and/or gloves to cover the color of their skin.

A common practice among participants was to ignore, or pretend not to hear, a street harasser's comments. Specifically, some participants, especially the young women who took part in the research, wore headphones to avoid hearing these comments. But as Davis (1994) points out, normally, when people talk to you, you do not ignore them. Thus, street harassment forces women to act in ways they would not otherwise act. Street harassment does not allow women to be themselves and to enjoy even the basic pleasures of everyday life (Rushin, 1983). A further strategy employed by many participants was the use of a male companion when in a public space. Griffin (1971) describes this as a "male protection racket," with Bowman (1993) concurring that women are often actively encouraged to seek a male escort when moving about in public spaces. Our participants certainly demonstrated this, 
with some saying "I never go to town alone" or "I prefer my husband to be with me" and "I don't think I would go anywhere without my husband." However, in some situations, this would exacerbate the abuse, especially if their husband was visibly Muslim, for example, by wearing a beard, Islamic cap, and jubba (Islamic dress for men). This need for a male companion has negative repercussions, in that it limits freedom of movement. One participant noted "I have to wait for my husband to come home from work to go somewhere." Another expressed this feeling of "imprisonment" in the starkest terms:

It feels like we are under house arrest. People have locked us up without realising it.

Another participant now has agoraphobia, and so does not leave the house. What was evident was the acute irony of the situation. As one noted,

People are being hypocritical in their argument that women in veil are oppressed because they oppress us. We are stuck at home all day.

This theme of "imprisonment" is commonplace in literature on the impact of street harassment. Bowman describes this as the ghettoization of women that effectively confines women to the "private sphere of hearth and home" (Bowman, 1993, p. 520). Street harassment excludes women from public space, which they are entitled to share with men as equal citizens of the state (Laniya, 2005). As mentioned earlier, public places are designated as male space, and women must negotiate the terms and conditions upon which they may enter these spaces. This means that street harassment infringes upon the rights of veiled Muslim women as citizens in the United Kingdom. To escape harassment, they often must travel with a male companion or in groups; this restricts a woman's autonomy by limiting her ability to 
go to a place by herself if she so desires and further reaffirms the notion that men control women's "rights to passage through public space" (Bowman, 1993, p. 30).

Oppression is the "absence of choices"; street harassment oppresses veiled Muslim women by restricting their physical and geographical mobility, thereby denying them a right guaranteed to all citizens - the freedom of movement, a fundamental liberty of freedom (Bowman, 1993). Indeed, a fundamental aspect of liberty is mobility; yet, free exercise of mobility is denied to veiled Muslim women. This also harms them economically because it dissuades them from venturing into occupations that require them to work outside (Laniya, 2005). It also forces behavioral change and reduces women's quality of life. Kissling (1991) argues that this is in fact the goal of street harassment, in that it acts as a form of social control. We would suggest that it acts on a number of levels. First, Muslim women think about modifying their clothing in public because they might want to feel that they "belong," not just avoid being attacked. One participant discussed how her family disproves of the niqab anyway, and so, she did not wear it when visiting them because she did not want to be an outcast everywhere. In this sense, the home might not be a place where the women are not judged or harassed because family might reinforce the public negative views of the niqab. So they feel a double sense of judgment as Muslim women. Furthermore, their recourse to go out with a male companion not only makes them reliant on men but also does not always mean that they will not face abuse. If the man is wearing a traditional Islamic dress, then they might still face abuse. So the social control that is experienced by Muslim women exists along misogynistic and Islamophobic lines. As Neilsen has observed, members of different groups and backgrounds "face a strikingly different reality on the street than do members of privileged groups" (Neilsen, 2002, p. 279). As such, they have to "prioritise social 
identities that are integral to their self-concepts and life experience" (Fogg-Davis, 2006, p. 59).

\section{Concluding thoughts - What next?}

The preceding discussion shows how street harassment, a seemingly "invisible" harm, hinders veiled Muslim women's mobility, infringes on their access to public spaces, and even forces them to alter their behavior. To this end, veiled Muslim women feel excluded, dominated, oppressed, and violated. Acting as "public gatekeepers," men establish the rules of veiled Muslim women's participation in the public sphere, which further genderizes the street. In this respect, street harassment "punishes" veiled Muslim women who participate in the street for not performing gender appropriately. Typically, most men view the occurrence as harmless and even desired by women, whereas most women resign themselves to the inevitability of the acts and the absence of a vehicle to remedy such harm (Laniya, 2005). Nevertheless, there is potentially hope to address this problem. Policy has an important role to play in tackling street harassment. Nottinghamshire Police became recently the first force in the country to record harassment of women as a hate crime to tackle misogyny and street harassment. Since then, three police forces have agreed to begin recording misogyny as a hate crime and a number of other forces are looking into this. The video, Because I Am A Woman, which was launched by Nottingham Women's Center and Nottinghamshire Police, includes testimony from Muslim women about their experiences of street harassment and has been used to raise awareness and as a training aid. There is now an emerging body of academic research that points toward the importance of recognizing intersectionality and multiple oppressions in victim experiences of hate crime (Zempi \& Chakraborti, 2014). It is crucial that research that engages with the lived experience of intersectionality and street harassment continues.

However, policy and research alone can only do so much to challenge Islamophobia and misogyny. It is crucial that continuing efforts include the involvement of Muslim women themselves and are culturally appropriate and sensitive. As Strid, Walby, and Armstrong (2013) note, multiple inequalities are only made more visible when

minoritized women are involved in the policy-making process. This means 
government and policy officials engaging with women themselves and for local community-based organizations to have a voice. Therefore, it is vital that policy makers and practitioners do not further the "othering" of Muslim women, but instead ensure their involvement at every stage. Future research should further examine the intersectionality between misogyny and Islamophobia, and inform policy accordingly.

\section{References}

Abu-Lughod, L. (2013). Do Muslim Women Need Saving? Cambridge: Harvard University Press.

Abu-Ras, W. \& Suarez, Z. (2009) 'Muslim Men and Women's Perception of Discrimination, Hate Crimes, and PTSD Symptoms Post 9/11', Traumatology, 15(3), 48-63.

Allen, C. (2015). 'People hate you because of the way you dress'. Understanding the invisible experiences of veiled British Muslim women victims of Islamophobia. International Review of Victimology, 21(3), 287-301.

Armstrong, L. (2016). “Who's the Slut, Who's the Whore?”: Street Harassment in the Workplace Among Female Sex Workers in New Zealand. Feminist Criminology, 11(3), 285-303.

Barker, M. (1981). The New Racism: Conservatives and the ideology of the tribe. London: Junction Books.

Bouteldja, N. (2011). Unveiling the Truth: Why 32 Muslim Women Wear the Full face Veil in France. London: Open Society Foundations.

Bowman, C. (1993). Street Harassment and the Informal Ghettoization of Women. Harvard Law Review, 106(3), 517-580.

Brems, E. (2014). Introduction to the volume. In E Brems (Ed.), The Experiences of Face Veil Wearers in Europe and the Law (pp. 1-17). Cambridge: Cambridge University Press.

Bullock, K. (2002). Rethinking Muslim women and the veil: Challenging historical and modern stereotypes. London: The International Institute of Islamic Thought.

Bullock, K., \& Jafri, G. J. (2002). Media (Mis) representations: Muslim women in the Canadian nation. Canadian Women's Studies, 20(2), 35-40.

Casey, L. (2016). The Casey Review: A Review into Opportunity and Integration. London: Crown. 
ComRes. (2016). Ahmadi Muslims - Perceptions of the Caliphate, ComRes: Surrey. Retrieved from http://www.comresglobal.com/wp-content/uploads/2016/05/AhmadiMuslims_Perceptions-of-the-Caliphate.pdf

Crenshaw, K. (1989). Demarginalizing the Intersection of Race and Sex: A Black Feminist Critique of Antidiscrimination Doctrine, Feminist Theory and Antiracist Politics. University of Chicago Legal Forum, 138-67.

Crenshaw, K. (1991). Mapping the Margins: Intersectionality, Identity Politics, and Violence against Women of Color, Stanford Law Review, 43(6), 1241-1299.

Curtis, B. \& Curtis, C. (2011). Social Research. London: Sage.

Davis, D. (1994). The Harm That Has No Name: Street Harassment, Embodiment, and African American Women. UCLA Women's Law Review, 4, 133-78.

Eisenstein, Z. (2006). Hatred written on the body. In P. Rothenberg (Ed.), Beyond borders (pp. 180-194). New York, NY: Worth

Fogg-Davis, H. (2006). Theorizing Black Lesbians with Black Feminism: A Critique of Same-Race Street Harassment. Politics \& Gender, 2, 57-76.

Franks, M. (2000). Crossing the Borders of Whiteness? White Muslim Women who Wear the Hijab in Britain Today. Ethnic and Racial Studies, 23(5), 917-929.

Freedman, J. (2007). Women, Islam and rights in Europe: Beyond a universalist/culturalist dichotomy. Review of Internationalist Studies, 33(1), 168-182

Gardner, C. B. (1995). Passing by: Gender and public harassment. Berkeley, CA: University of California Press.

Glaser, B.G. (1992). Emergence vs Forcing: Basics of Grounded Theory Analysis. Mill Valley, CA: Sociology Press.

Glaser, B. \& Strauss, A. (1967). The discovery of grounded theory. Chicago: Aldine. Goffman, E. (1990). The presentation of self in everyday life. London: Penguin.

Griffin, S. (1971). Rape: The All-American Crime. Oz, issue 41, pp28.

Harris, A. P. (1990). Race and Essentialism in Feminist Legal Theory. Stanford Law Review, 42(3), 581-616.

Hennink, M., Hutter, I. \& Bailey, A. (2011). Qualitative Research Methods. London: Sage.

Ilahi, N. (2009). Gendered Contestations: An Analysis of Street Harassment in Cairo and its Implications for Access to Public Spaces. Surfacing, 2(1), 56-69. 
Kelly, L. (1988). Surviving sexual violence. Oxford: Polity Press.

Kissling, E. (1991). Sexual harassment: The language of sexual terrorism. Discourse \& Society, 2, 451-460.

Kissling, E. \& Kramarae, C. (1991). Stranger Compliments: The Interpretation of Street Remarks. Women's Studies in Communication, 77-95.

Laniya, O. (2005). Street Smut: Gender, Media, and the Legal Power Dynamics of Street Harassment, or Hey Sexy and Other Verbal Ejaculations. Columbia Journal of Gender and Law, 14(1), 91-142.

Larkin, J. (1997). Sexual terrorism on the street: The moulding of young women into subordination. In A. M. Thomas, \& C. Kitzinger (Eds.), Sexual harassment: Contemporary feminist perspectives (pp. 115-130). Buckingham: Open University Press.

Lloyd, M. (2005). Beyond Identity Politics: Feminism, Power and Politics. UK: Sage. MacKinnon, C. (1987). Feminism Unmodified. Cambridge: Harvard University Press. Moors, A. (2009). The Dutch and the Face-Veil: The Politics of Discomfort. Social Anthropology, 17(4), 393-408.

Moors, A. (2014). Face veiling in the Netherlands: public debates and women's narratives. In E Brems (Ed.), The Experiences of Face Veil Wearers in Europe and the Law (pp. 19-41). Cambridge: Cambridge University Press.

Neilsen, L. (2002). Subtle, Pervasive, Harmful: Racist and Sexist Remarks in Public as Hate Speech. Journal of Social Issues, 58(2), 265-280.

Okely, J. (2007). Fieldwork Embodied. In C Shilling (Ed.), Embodying Sociology: Retrospect, Progress and Prospects. Oxford: Blackwell Publishers.

Payne, S. (2004). Designing and conducting qualitative studies. In S. Michie, \& C. Abraham (Eds.), Health psychology in practice (pp. 126-149). London: Routledge.

Perry, B. (2014). Gendered Islamophobia: hate crime against Muslim women. Social Identities, 20, 74-89.

Randall, M. (1987). Sexual harassment. Toronto: Ontario Women's Directorate.

Rushin, D. K. (1983). The Tired Poem Last Letter from a Typical Unemployed Black Professional Woman. Cond, 79(5), 72-76.

Sallah, M. (2010). The Ummah and Ethnicity: Listening to the Voices of African Heritage Muslims in Leicester. Leicester: Leicester City Council.

Spelman, E. V. (1990). Inessential Woman. London: The Women's Press. 
Strid, S., Walby, S. \& Armstrong, J. (2013). Intersectionality and Multiple Inequalities: Visibility in British Policy on Violence Against Women. Social Politics, 20(4), 558581.

Tuerkheimer, D. (1997). Street harassment as sexual subordination: The phenomenology of gender-specific harm. Wisconsin Women's Law Journal, 12, 167206.

Vera-Gray, F. (2016). Men's Stranger Intrusions: Re-thinking Street Harassment. Women's Studies International Forum, 58, 9-17.

Wise, S., \& Stanley, L. (1987). Georgie Porgie: Sexual harassment in everyday life. London: Pandora Press.

Young, I. M. (1990). Justice and the politics of difference. Princeton, NJ: Princeton University Press.

Zubair, M., Martin, W. \& Victor, C. (2012). Embodying gender, age, ethnicity and power in 'the field': reflections on dress and the presentation of the self in research with older Pakistani Muslims. Sociological Research Online, 17(3). http://www.socresonline.org.uk/17/3/21.html. 